\title{
Tintinnid community structure in the eastern equatorial Indian Ocean during the spring inter-monsoon period
}

\author{
Cuixia Zhang ${ }^{1,2}$, Jun Sun ${ }^{1,2, *}$, Dongxiao Wang ${ }^{3}$, Shuqun Song ${ }^{4}$, Xiaodong Zhang ${ }^{1}$, \\ Sonia Munir ${ }^{1}$ \\ ${ }^{1}$ College of Marine and Environmental Sciences, Tianjin University of Science and Technology, Tianjin 300457, PR China \\ ${ }^{2}$ Tianjin Key Laboratory of Marine Resources and Chemistry, Tianjin University of Science and Technology, Tianjin 300457, PR China \\ ${ }^{3}$ State Key Laboratory of Tropical Oceanography (LTO), South China Sea Institute of Oceanology, \\ Chinese Academy of Sciences, Guangzhou 510301, PR China
}

${ }^{4}$ Key Laboratory of Marine Ecology and Environmental Sciences, Institute of Oceanology, Chinese Academy of Sciences, Qingdao 266071, PR China

\begin{abstract}
Tintinnid community structure was investigated by plankton net $(20 \mu \mathrm{m})$ sampling in the water column $(0-200 \mathrm{~m})$ at 33 stations during the spring inter-monsoon (10 March to 9 April 2012) in the eastern equatorial Indian Ocean. A total of 126 species belonging to 32 genera were recorded. Tintinnid abundance and biomass in the range of 193-2983 ind. $\mathrm{m}^{-3}$ and $0.99-14.75 \mu \mathrm{g}$ $\mathrm{C} \mathrm{m}^{-3}$ were positively related to integrated chlorophyll a $(\mathrm{chl}$ a) concentration. Taxonomic and morphological diversity were not significantly related to integrated chl a concentration and size diversity, estimated by size-fractionated chl a concentration in the water column of $0-200 \mathrm{~m}$, but were negatively correlated to the depth of the deep chlorophyll maximum. Species abundance distributions at most stations (31 of 33) and in the 3 zones - the northern zone of the equator, the southern zone of the equator (SEQ) and the equator (EQ) - followed a typical lognormal distribution. The geometric distribution gave the best fit for the distribution of lorica oral diameter sizeclasses in the NEQ and SEQ. Our results suggest that the community structure of tintinnids is governed by the underlying water column environment rather than by the neutral theory of random colonization from a large species pool.
\end{abstract}

KEY WORDS: Tintinnid community $\cdot$ Species diversity $\cdot$ Species abundance distribution $\cdot$ Eastern equatorial Indian Ocean

\section{INTRODUCTION}

Tintinnids are characterized by the possession of a lorica, which is thought to protect the cell from predators, facilitate escape by rapid sinking and assist filter feeding (Agatha et al. 2013). Lorica morphology not only forms the basis of tintinnid identification, but also provides information on the ecology of the organism. The maximum size of natural prey ingested and preferred prey size are closely related to lorica oral diameter (LOD) (Dolan 2010). Much

${ }^{*}$ Corresponding author: phytoplankton@163.com research has been carried out on the biogeography of oceanic tintinnids, such as in the tropical Pacific Ocean (Dolan et al. 2007), the Mediterranean Sea (Dolan et al. 1999, Dolan 2000, Modigh et al. 2003), the Arctic Ocean (Feng et al. 2014), the Southern Ocean (Dolan et al. 2012) and the Atlantic Ocean (Thompson \& Alder 2005). According to a recent report on tintinnid global biogeography (Dolan \& Pierce 2013), only a few species are recorded in the eastern Indian Ocean (Modigh et al. 2003, Liu et al. 2012).

(C) The authors 2017. Open Access under Creative Commons by Attribution Licence. Use, distribution and reproduction are unrestricted. Authors and original publication must be credited. 
Tintinnid ciliates are a common component of planktonic microzooplankton and occur in all of the world's oceans (Pierce \& Turner 1992, 1993). Although only a small proportion of total microzooplankton, tintinnids are much more abundant than other groups (e.g. foraminifera and radiolarians). Tintinnids are secondary consumers at the base of the food web, grazing mainly on nanoplankton, as well as on picoplankton (Dolan et al. 2006a). As copepods are seldom able to prey directly on the dominating primary producers in oligotrophic tropical systems (Calbet \& Landry 1999), the microbial food web performs a crucial role in the transfer of energy up the food chain.

A species abundance distribution (SAD) was used in the study. This is one of the most common descriptions of community structure and describes the abundance (number of individuals observed) for each species encountered within a community (McGill et al. 2007). The different SAD ecological models can reflect different mechanisms regulating the occurrence and abundance of individual species, e.g. species interactions, random chance or some other factor. A lognormal SAD is the most common pattern and is described as canonical by pure statistical theory when large assemblages occur (Magurran 2004). It expresses a community in which populations are subjected to random variations or are affected by several interacting factors. The geometric distribution is often thought to be a model in which each species takes a constant fraction of the remaining resources (Whittaker 1972). The log-series distribution and the metacommunity zero-sum multinomial (mZSM) distribution are 2 different models for the unified neutral theory of biodiversity. The theory suggests that species actually found in any given community are the result of stochastic processes of immigration, speciation and local extinction (Hubbell 2001). The log-series distribution is a limiting case of mZSM, and Hubbell's fundamental biodiversity number, $\theta$, tends to Fisher's alpha as the number of individuals in the sample increases.

Most research reveals that the tintinnid community with SAD described by a log-series distribution is structured by dispersal limitation coherent with the unified neutral theory in the oligotrophic eastern Pacific (Dolan et al. 2007) and in the open water of the Mediterranean Sea (Dolan et al. 2009, 2013, Raybaud et al. 2009). In contrast, SAD of tintinnids in the coastal Mediterranean Sea show a log-normal pattern, indicating that the community seems to be shaped by environmental condition rather than neutral processes (Sitran et al. 2009). Such information is still missing for other ocean areas.
Our investigation was carried out in the open region of the eastern equatorial Indian Ocean $\left(80-94^{\circ} \mathrm{E}, 6-5^{\circ} \mathrm{S}\right)$ during the spring inter-monsoon period (10 March-9 April 2012). Indian Ocean circulations forced by monsoon winds are very different from those in other oceans. They generally blow from the southwest during May to September (summer monsoon) and from the northeast during November to February (winter monsoon) over the north Indian Ocean, March to April and October being transition months with weak winds (Shankar et al. 2002). There is no equatorial upwelling in the equatorial Indian Ocean, which is considered a typical tropical ultraoligotrophic ocean and is relatively far from coastal influences (Schott et al. 2002). The eastward-propagating spring Wyrtki jets are strongest from April to May (Murtugudde et al. 2000); the main biogeochemical impact of the jets is a depression of the thermocline and nitracline on the eastern side of the basin and a decrease in primary production in May (Wiggert et al. 2006, Strutton et al. 2015).

Average chlorophyll a ( $\mathrm{chl}$ a) concentration in the eastern equatorial Indian Ocean is notably lower than that in other open oceans (e.g. Pacific Ocean, Mediterranean Sea). Inter-monsoon periods represent ultra-oligotrophic seasons with low production (Longhurst 2007). Examination of tintinnid diversity suggests it may be more closely related to food resource or its diversity than competitive interactions or predation (Dolan et al. 2002). Reports of the relationship between tintinnid diversity and chl a concentration in oceanic waters are varied: weak or non-significant (Dolan et al. 2002, 2007, Thompson 2004), showing negative correlation (Dolan 2000) or showing positive correlation (Santoferrara \& Alder 2012). We expected to find that tintinnid community diversity was not notably related to food resources, that is, chl a concentration. In this study, the following questions were addressed through basic analysis of community diversity and water column structure: (1) Is tintinnid diversity significantly related to chl a concentration and chl $a$ size diversity, estimated by size-fractionated $\mathrm{chl} a$ concentration? (2) What is the mechanism that regulates the occurrence and abundance of individual tintinnid species in terms of community SAD?

\section{MATERIALS AND METHODS}

\section{Sampling and sample analysis}

The study was carried out in the eastern equatorial Indian Ocean $\left(80-94^{\circ} \mathrm{E}, 6^{\circ} \mathrm{N}-5^{\circ} \mathrm{S}\right)$ (Fig. 1) onboard 


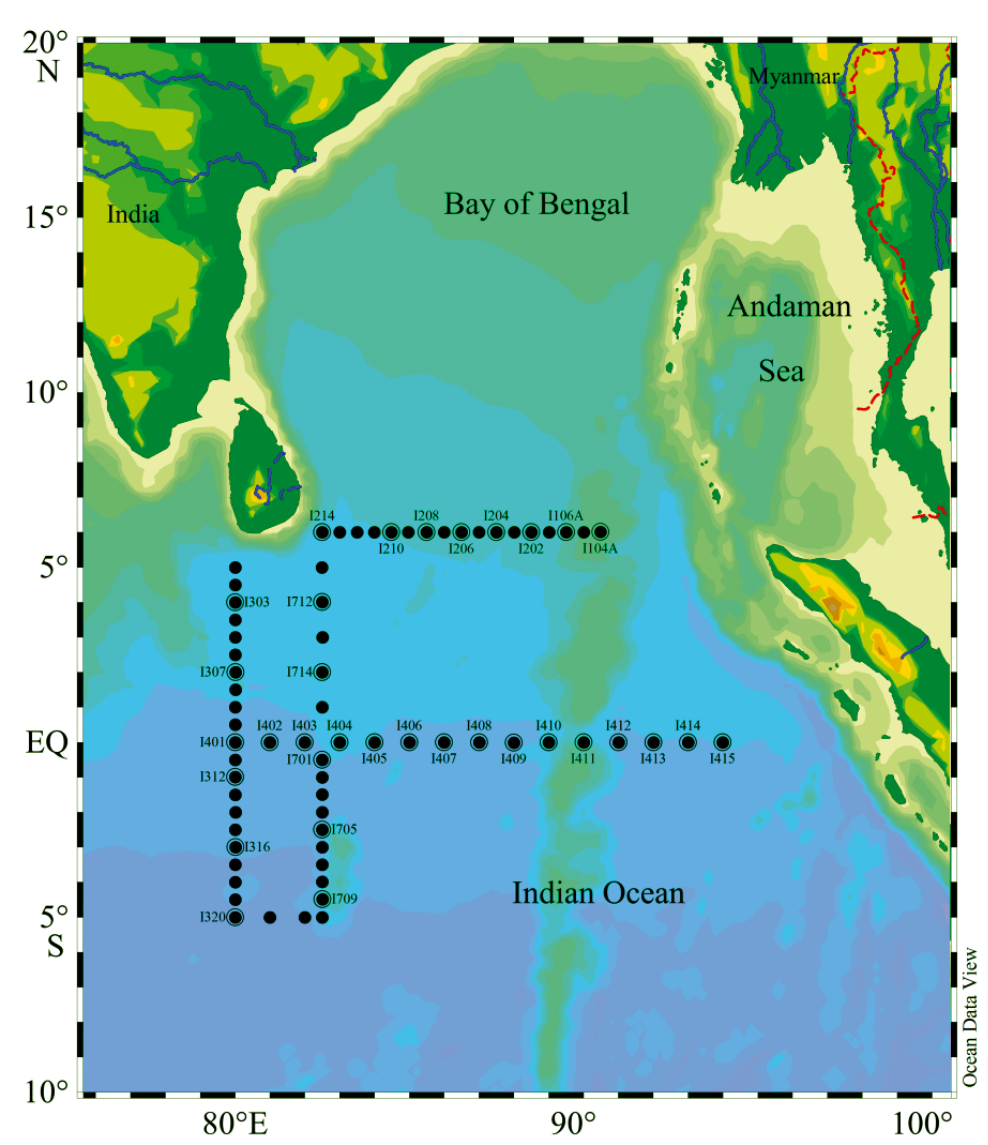

Fig. 1. Study area in the eastern equatorial Indian Ocean showing sampling stations. Labels denote the tintinnid trawling stations (circled points); water depth increases from light to dark

RV 'Shiyan 1' from 10 March to 9 April 2012. Hydrological data were obtained from an average depth of $200 \mathrm{~m}$ from all of the 69 oceanographic stations located in the 4 transects (see Fig. 2) with a Sea-Bird SBE-911 Plus V2 conductivity-temperature-depth (CTD) system. The transects included the equator, $6^{\circ} \mathrm{N}, 80^{\circ} \mathrm{E}$ and $82.5^{\circ} \mathrm{E}$ transects. Potential density anomaly was calculated from temperature, salinity and depth data in Ocean Data View (https:// odv.awi.de/fileadmin/user_upload/odv/misc/odv4 Guide.pdf). The depth of the deep chlorophyll maximum (DCM) layer was determined by chlorophyll fluorescence data. Samples for chl a concentration were collected at 8 discrete depths, including the DCM layer, from surface water to $200 \mathrm{~m}$ by CTDmounted rosette assemblies with twelve 51 Niskin bottles (General Oceanic) during the deployment.

A sample of $800 \mathrm{ml}$ seawater from each layer was filtered through a sequence of $20 \mu \mathrm{m}$ mesh, $2 \mu \mathrm{m}$ cellulose filters and Whatman GF/F glass fiber filters for size-fractionated micro-, nano- and pico-chl a concentrations. Total chl a concentration was the sum of the size-fractionated chl a concentrations. The filters were preserved at $-20^{\circ} \mathrm{C}$ for the duration of the cruise. In the laboratory, these were extracted using $90 \%$ aqueous acetone and maintained at $-20^{\circ} \mathrm{C}$ in the dark for $24 \mathrm{~h}$. Size-fractionated chl a concentration was determined fluorometrically (Parsons et al. 1984) using a Turner Designs fluorometer.

Tintinnids were sampled with a custommade $20 \mu \mathrm{m}$ mesh plankton net $(80 \mathrm{~cm}$ mouth diameter, $0.5 \mathrm{~m}^{2}$ mouth area, total length $280 \mathrm{~cm}$ ), which was hauled vertically from a depth of $200 \mathrm{~m}$ to the surface at a hauling speed of $0.5 \mathrm{~m} \mathrm{~s}^{-1}$ at 33 biological stations (Table 1). The samples were preserved in neutralized formaldehyde seawater solution at a final concentration of approximately $5 \%$ until analyzed in the laboratory. After thorough mixing, a $2.5 \mathrm{~cm}^{3}$ subsample was settled in a sedimentation chamber and examined under an inverted microscope (MOTIC AE2000) at magnifications of $\times 100-400$. At least 200-300 cells (lorica with protoplast) were counted, excluding those with empty lorica because of their occasional appearance, and 2-3 replicate subsamples in each sample were examined for rare species.

Species identification was based on lorica morphology using taxonomic monographs (Kofoid \& Campbell 1929, 1939, Marshall 1969) and relevant references (Hada 1938, Bachy et al. 2012). LOD and length of each cell were measured using Motic Images Advanced 3.2 Software; volume was determined by measuring cell dimensions assuming appropriate geometric shapes (ellipsoid, cone, cylinder, ball, semi-ellipsoid and combinations). The carbon biomass of each cell was estimated using the carbon to lorica volume conversion factor $0.053 \mathrm{pg} \mathrm{C} \mathrm{mm}^{-3}$ (Verity \& Langdon 1984). For each station, cell abundance and biomass were calculated from total cell counts of the sample divided by filtered seawater volume $\left(100 \mathrm{~m}^{3}\right)$ from the cylindrical water column at $0-200 \mathrm{~m}$. The categories of genera geographic distribution patterns were assigned according to Dolan \& Pierce (2013).

\section{Data analysis}

Species richness was the total number of species found at each station. Tintinnid community diversity was estimated by taxonomic and morphological diversity. Taxonomic diversity comprised species rich- 
Table 1. Sampling and tintinnid community data for each station. Chl a concentration at the depth of the deep chlorophyll maximum (DCM) and integrated chl a concentration throughout trawling of the water column of 0-200 m are also given

\begin{tabular}{|c|c|c|c|c|c|c|c|c|}
\hline Station & Longitude & Latitude & $\begin{array}{c}\text { Date } \\
\text { sampled }\end{array}$ & $\begin{array}{c}\text { No. } \\
\text { species }\end{array}$ & $\begin{array}{l}\text { Abundance } \\
\left(\text { cells m }{ }^{-3}\right)\end{array}$ & $\begin{array}{l}\text { Biomass } \\
\left(\mu \mathrm{C} \mathrm{C} \mathrm{m}^{-3}\right)\end{array}$ & $\begin{array}{c}\mathrm{DCM} \mathrm{chl} \mathrm{a} \\
\left(\mathrm{mg} \mathrm{m}^{-3}\right)\end{array}$ & $\begin{array}{c}\text { Integrated chl } a \\
\left(\mathrm{mg} \mathrm{m}^{-3}\right)\end{array}$ \\
\hline $\mathrm{I} 104 \mathrm{~A}$ & $90^{\circ} 29.5^{\prime} \mathrm{E}$ & $6^{\circ} 0.3^{\prime} \mathrm{N}$ & 10 Mar & 43 & 207 & 1.35 & 0.333 & 27.72 \\
\hline I106A & $89^{\circ} 29.8^{\prime} \mathrm{E}$ & $6^{\circ} 0.1^{\prime} \mathrm{N}$ & 11 Mar & 59 & 2983 & 14.58 & 0.590 & 35.42 \\
\hline $\mathrm{I} 202$ & $88^{\circ} 30.2^{\prime} \mathrm{E}$ & $6^{\circ} 0.0^{\prime} \mathrm{N}$ & $12 \mathrm{Mar}$ & 55 & 707 & 3.51 & 0.581 & 35.23 \\
\hline I204 & $87^{\circ} 30.1^{\prime} \mathrm{E}$ & $6^{\circ} 0.0^{\prime} \mathrm{N}$ & $13 \mathrm{Mar}$ & 61 & 657 & 6.01 & 0.519 & 32.07 \\
\hline I206 & $86^{\circ} 30.0^{\prime} \mathrm{E}$ & $6^{\circ} 0.0^{\prime} \mathrm{N}$ & $14 \mathrm{Mar}$ & 47 & 193 & 0.99 & 0.290 & 26.51 \\
\hline I208 & $85^{\circ} 30.0^{\prime} \mathrm{E}$ & $6^{\circ} 0.0^{\prime} \mathrm{N}$ & 14 Mar & 57 & 698 & 4.34 & 0.528 & 25.33 \\
\hline I 210 & $84^{\circ} 30.0^{\prime} \mathrm{E}$ & $6^{\circ} 0.0^{\prime} \mathrm{N}$ & $15 \mathrm{Mar}$ & 54 & 761 & 5.94 & 0.739 & 43.21 \\
\hline I214 & $83^{\circ} 30.0^{\prime} \mathrm{E}$ & $6^{\circ} 0.1^{\prime} \mathrm{N}$ & 16 Mar & 50 & 226 & 1.54 & 0.239 & 18.70 \\
\hline $\mathrm{I} 712$ & $82^{\circ} 30.2^{\prime} \mathrm{E}$ & $4^{\circ} 0.3^{\prime} \mathrm{N}$ & 17 Mar & 62 & 2411 & 14.75 & 0.322 & 29.33 \\
\hline I714 & $82^{\circ} 30.1^{\prime} \mathrm{E}$ & $2^{\circ} 0.0^{\prime} \mathrm{N}$ & 18 Mar & 62 & 1351 & 9.18 & 0.507 & 42.89 \\
\hline I701 & $82^{\circ} 30.0^{\prime} \mathrm{E}$ & $0^{\circ} 30.0^{\prime} \mathrm{S}$ & 19 Mar & 48 & 368 & 2.00 & 0.428 & 30.07 \\
\hline I705 & $82^{\circ} 30.0^{\prime} \mathrm{E}$ & $2^{\circ} 30.0^{\prime} \mathrm{S}$ & $20 \mathrm{Mar}$ & 53 & 377 & 2.20 & 0.415 & 33.27 \\
\hline I709 & $82^{\circ} 30.3^{\prime} \mathrm{E}$ & $4^{\circ} 30.0^{\prime} \mathrm{S}$ & $21 \mathrm{Mar}$ & 48 & 1390 & 7.26 & 0.391 & 30.18 \\
\hline I320 & $80^{\circ} 0.0^{\prime} \mathrm{E}$ & $5^{\circ} 0.0^{\prime} \mathrm{S}$ & 22 Mar & 61 & 948 & 5.98 & 0.448 & 37.01 \\
\hline I316 & $80^{\circ} 0.8^{\prime} \mathrm{E}$ & $3^{\circ} 0.0^{\prime} \mathrm{S}$ & $23 \mathrm{Mar}$ & 52 & 1799 & 9.23 & 0.389 & 33.83 \\
\hline I312 & $80^{\circ} 0.0^{\prime} \mathrm{E}$ & $1^{\circ} 0.0^{\prime} \mathrm{S}$ & 24 Mar & 44 & 342 & 1.66 & 0.338 & 29.69 \\
\hline I307 & $80^{\circ} 0.0^{\prime} \mathrm{E}$ & $2^{\circ} 0.0^{\prime} \mathrm{N}$ & $26 \mathrm{Mar}$ & 58 & 665 & 3.38 & 0.580 & 35.02 \\
\hline I303 & $80^{\circ} 0.0^{\prime} \mathrm{E}$ & $4^{\circ} 0.2^{\prime} \mathrm{N}$ & $1 \mathrm{Apr}$ & 53 & 979 & 5.25 & 0.493 & 37.51 \\
\hline I401 & $80^{\circ} 0.0^{\prime} \mathrm{E}$ & $0^{\circ} 0.0^{\prime} \mathrm{N}$ & 25 Mar & 47 & 1107 & 7.16 & 0.590 & 43.92 \\
\hline $\mathrm{I} 402$ & $81^{\circ} 0.0^{\prime} \mathrm{E}$ & $0^{\circ} 0.0^{\prime} \mathrm{N}$ & $3 \mathrm{Apr}$ & 49 & 265 & 2.43 & 0.568 & 36.14 \\
\hline $\mathrm{I} 403$ & $82^{\circ} 0.0^{\prime} \mathrm{E}$ & $0^{\circ} 0.0^{\prime} \mathrm{N}$ & $3 \mathrm{Apr}$ & 51 & 759 & 3.77 & 0.422 & 37.18 \\
\hline I404 & $83^{\circ} 0.0^{\prime} \mathrm{E}$ & $0^{\circ} 0.0^{\prime} \mathrm{N}$ & $4 \mathrm{Apr}$ & 51 & 1158 & 6.34 & 0.565 & 37.08 \\
\hline I405 & $84^{\circ} 0.0^{\prime} \mathrm{E}$ & $0^{\circ} 0.0^{\prime} \mathrm{N}$ & $4 \mathrm{Apr}$ & 48 & 505 & 2.55 & 0.523 & 32.83 \\
\hline I406 & $85^{\circ} 0.0^{\prime} \mathrm{E}$ & $0^{\circ} 0.0^{\prime} \mathrm{N}$ & $5 \mathrm{Apr}$ & 39 & 210 & 1.80 & 0.516 & 35.73 \\
\hline $\mathrm{I} 407$ & $86^{\circ} 0.2^{\prime} \mathrm{E}$ & $0^{\circ} 0.0^{\prime} \mathrm{N}$ & $5 \mathrm{Apr}$ & 43 & 1379 & 9.67 & 0.453 & 33.34 \\
\hline I408 & $87^{\circ} 0.3^{\prime} \mathrm{E}$ & $0^{\circ} 0.0^{\prime} \mathrm{N}$ & $6 \mathrm{Apr}$ & 47 & 1025 & 7.32 & 0.340 & 28.56 \\
\hline I409 & $88^{\circ} 0.0^{\prime} \mathrm{E}$ & $0^{\circ} 0.0^{\prime} \mathrm{N}$ & 7 Apr & 42 & 1045 & 5.69 & 0.372 & 26.90 \\
\hline I410 & $89^{\circ} 0.0^{\prime} \mathrm{E}$ & $0^{\circ} 0.0^{\prime} \mathrm{N}$ & $7 \mathrm{Apr}$ & 56 & 1160 & 5.85 & 0.513 & 33.35 \\
\hline I411 & $90^{\circ} 0.2^{\prime} \mathrm{E}$ & $0^{\circ} 0.0^{\prime} \mathrm{N}$ & $7 \mathrm{Apr}$ & 49 & 1172 & 7.76 & 0.733 & 42.44 \\
\hline I412 & $91^{\circ} 0.5^{\prime} \mathrm{E}$ & $0^{\circ} 0.0^{\prime} \mathrm{N}$ & $8 \mathrm{Apr}$ & 46 & 1309 & 9.07 & 0.680 & 41.62 \\
\hline $\mathrm{I} 413$ & $92^{\circ} 0.4^{\prime} \mathrm{E}$ & $0^{\circ} 0.0^{\prime} \mathrm{N}$ & $8 \mathrm{Apr}$ & 49 & 682 & 3.67 & 0.645 & 39.40 \\
\hline I 414 & $93^{\circ} 0.0^{\prime} \mathrm{E}$ & $0^{\circ} 0.0^{\prime} \mathrm{N}$ & 9 Apr & 50 & 431 & 2.57 & 0.325 & 25.61 \\
\hline I4415 & $94^{\circ} 00^{\prime} \mathrm{E}$ & $0^{\circ} 0.0^{\prime} \mathrm{N}$ & $9 \mathrm{Apr}$ & 52 & 593 & 3.03 & 0.545 & 46.46 \\
\hline
\end{tabular}

ness, the Shannon-Wiener index (Magurran 2004, ln-based expression) and Fisher's alpha. Lorica dimensions comprised LOD, lorica length and lorica volume. Intervals of $4 \mu \mathrm{m}$ were used as the LOD sizeclasses and lorica length from the smallest to the maximum value, respectively (Dolan 2010). Morphological diversity comprised LOD measurements (in $4 \mu \mathrm{m}$ size-classes) and the Shannon-Wiener index of LODs (LOD- $H^{\prime}$ ) (Magurran 2004, Dolan et al. 2007). LOD size-class as a substitute for species was calculated to evaluate the LOD Shannon-Wiener index.

Integrated total chl a concentration and chlorophyll of pico-, nano- and micro-size in the water column $(0-200 \mathrm{~m})$ were calculated according to the trapezoidal method. Chl a size-class diversity was evaluated by calculating the Shannon-Wiener index (chl a- $H^{\prime}$ ) considering integrated water column concentration of pico-, nano- and micro-chlorophyll as 3 size fractions (Dolan et al. 2002, Dolan et al. 2007).
Pearson correlation was used to assess linear relationships between tintinnid abundance, biomass, species richness and integrated chl a concentration using SPSS 19.3 (IBM). Monotonic relationships among the metrics of tintinnid diversity, abundance and chl a concentration characteristics were evaluated by nonparametric Spearman's rank order correlation coefficients, based on the ranked values for each variable rather than on the raw data.

SADs were used to describe the variation of abundance for each species with species rank from highest to lowest, which was visualized in a rankabundance diagram. SADs were fitted using 4 common distribution models by the maximum likelihood method with the following numerical optimization: geometric, log-normal, log-series and mZSM distribution. Fitting of the models was carried out and natural logarithm of maximum likelihood estimators (log-likelihood) were calculated using the sads pack- 
age (Prado \& Miranda 2015) in the R program. Akaike's information criterion (AIC) was determined as log-likelihood multiplication by the constant $(-2)$, plus the bias-correction term: $(S+K) /(S-K-2)$ where $S$ is the number of species and $K$ is the number of estimable parameters ( 1 for geometric and 2 each for log-normal, log-series and mZSM distribution) (Burnham \& Anderson 2002, Dolan et al. 2007). AIC of fit test was used for selecting the best model: the smaller the AIC, the better the fit. As the scale of the investigation area was limited, 3 geographic zones were designated to simplify redundant data at different stations. The 3 zones were divided by the boundary of the equator: the equator (EQ), the northern zone of the equator (NEQ) and the southern zone of the equator (SEQ).

\section{RESULTS}

\section{Hydrographic features and chlorophyll}

There was a thermo-/pycnocline between 50 and $100 \mathrm{~m}$, according to the vertical measurements of temperature, salinity and potential density in the equator and $6^{\circ} \mathrm{N}$ transects (Fig. 2). Correspondingly, the DCM layer occurred at a depth of $100 \mathrm{~m}$ at Stns I407-I415. However, the thermocline and halocline weakened, and the depth of the upper mixed layer decreased to less than $100 \mathrm{~m}$ in the $80^{\circ} \mathrm{E}$ and $82.5^{\circ} \mathrm{E}$ transects, where the DCM layers were mainly found at either 50 or $75 \mathrm{~m}$. Chl a concentration in the DCM layer ranged from $0.239 \mathrm{mg} \mathrm{m}^{-3}$ at Stn I214 to $0.739 \mathrm{mg} \mathrm{m}^{-3}$ at Stn I210. Average chl a concentration in all water layers was $0.17 \mathrm{mg} \mathrm{m}^{-3}(0.007-0.739 \mathrm{mg}$ $\mathrm{m}^{-3}$ ). Integrated $\mathrm{chl}$ a concentration in the $200 \mathrm{~m}$ water column ranged from $18.70 \mathrm{mg} \mathrm{m}^{-2}$ (Stn I214) to $46.46 \mathrm{mg} \mathrm{m}^{-2}$ (Stn I415). Examination of the size fraction of integrated chl a concentration in the water column $(0-200 \mathrm{~m})$ showed that pico-chl a represented on average $74.1 \%$ of the total chl a concentration, followed by nano-chl $a$ at $22.2 \%$.

\section{Taxonomic composition}

A total of 126 tintinnid species belonging to 32 genera were found, of which only 1 was not identified to species level (see Table S1 in the Supplement at www.int-res.com/articles/suppl/b026p087_supp.pdf). Species composition was dominated by those with a hyaline lorica rather than those with an agglutinated lorica. According to previously reported biogeographic distribution patterns of common tintinnid genera, 12 belonged to cosmopolitan genera, including hyaline and agglutinating species, which are quite widespread in the world's oceans. A total of 17 warmwater genera with hyaline lorica were identified, of which Brandtiella, Xystonellopsis, Codonaria and Climacocylis are unique to tropical and subtropical waters. Tintinnopsis and Stenosemella, which were recorded at 13 stations, are neritic genera composed of species with agglutinated lorica.

LOD ranged from 8 to $117 \mu \mathrm{m}$. A total of 15 LOD size-classes were occupied and species in the sizeclasses 28-32, 33-37 and 58-62 $\mu \mathrm{m}$ were most numerous ( $>17$ ) (Fig. 3A). Lorica lengths of most species were in the range of 39-123 $\mu \mathrm{m}$, which accounted for $62.6 \%$ of the total species number (Fig. 3B). Salpingacantha ampla had the longest lorica of $403 \mu \mathrm{m}$ on average, followed by Xystonella treforti with a lorica length of $394 \mu \mathrm{m}$ at all stations. Lorica volume of $83 \%$ species was distributed in the range of $2.2 \times 10^{4}-3.9 \times$

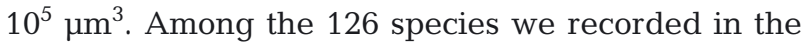
eastern equatorial Indian Ocean, 22 rare species were found at only 1 or 2 stations, with most species occurring at 3 to 6 stations. A total of 16 species were found at 31 to 33 stations (Fig. 3D).

\section{Distribution and diversity patterns}

Tintinnid abundance ranged from 193 ind. $\mathrm{m}^{-3}$ (Stn I206) to 2983 ind. $\mathrm{m}^{-3}$ (Stn I106A), and biomass from $0.99 \mu \mathrm{g} \mathrm{C} \mathrm{m}{ }^{-3}$ (Stn I206) to $14.75 \mu \mathrm{g} \mathrm{C} \mathrm{m}^{-3}$ (Stn I712). Tintinnid species spatial distribution, as a percentage of sampling stations occupied, was positively correlated with overall average species abundance (Pearson's $r=0.82, \mathrm{p}<0.01, \mathrm{n}=126$; Fig. 4A). LOD size and occurrence rate as a percentage of stations occupied were not correlated (Fig. 4B). The most widespread LOD sizes fell within the narrow range of $20-70 \mu \mathrm{m}$.

After log transformation, tintinnid abundance and biomass were significantly correlated with integrated chl a concentration (Pearson correlation coefficients, $r=0.39, p=0.02 ; r=0.42, p=0.01$; Fig. 5A,B). There was no relationship between species richness and integrated chl a concentration $(\mathrm{r}=0.14, \mathrm{p}=0.45$; Fig. 5C, Table 2).

From the Spearman's rank correlation coefficients among diversity indexes, abundance and chl a concentrations, only Fisher's alpha was significantly correlated to $\log _{10}$ (abundance) $(\rho=-0.81, p<0.01$; Table 2). However, $\log _{10}$ (abundance) and species richness followed a normal distribution according to 

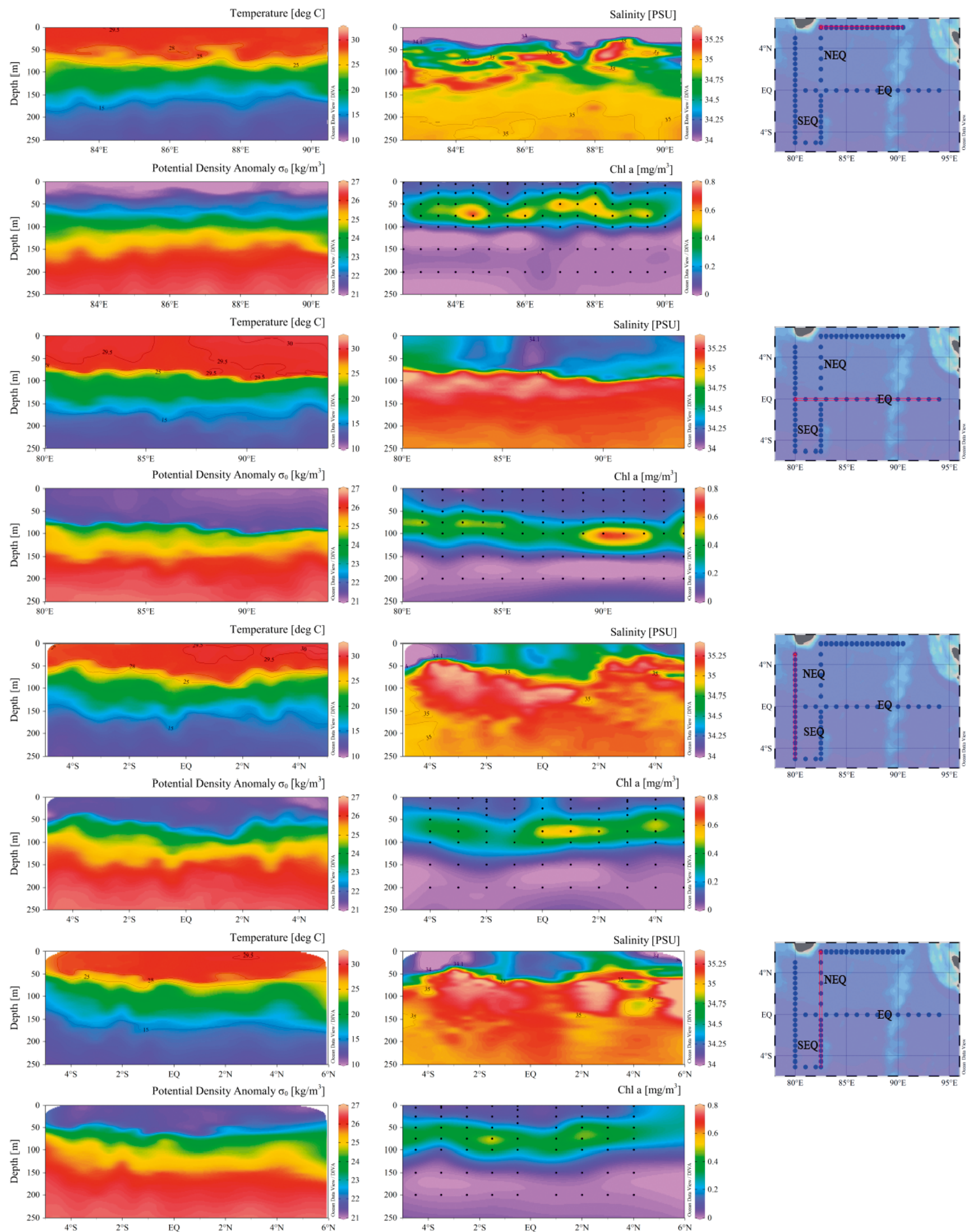

Fig. 2. Vertical distributions of temperature, salinity, potential density and chl a concentration in the 4 transects. EQ: equator; NEQ: northern zone; SEQ: southern zone 


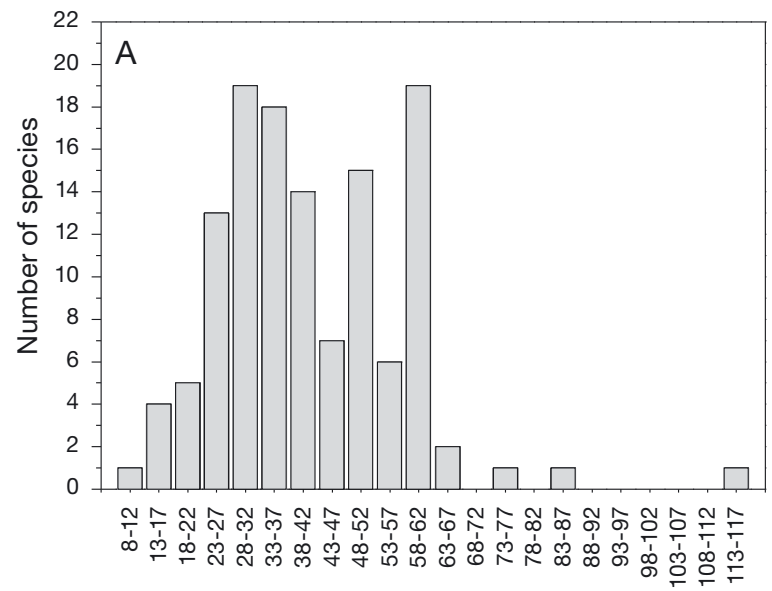

Lorica oral diameter $(\mu \mathrm{m})$

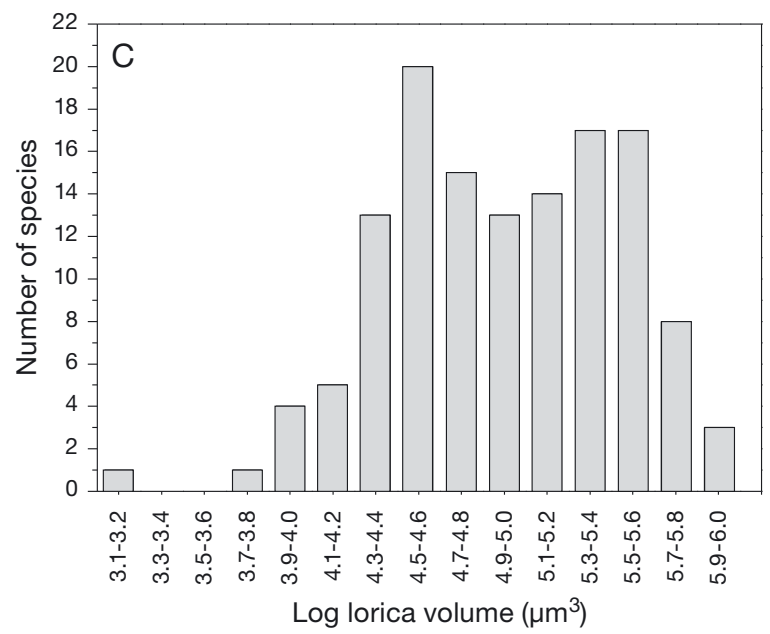

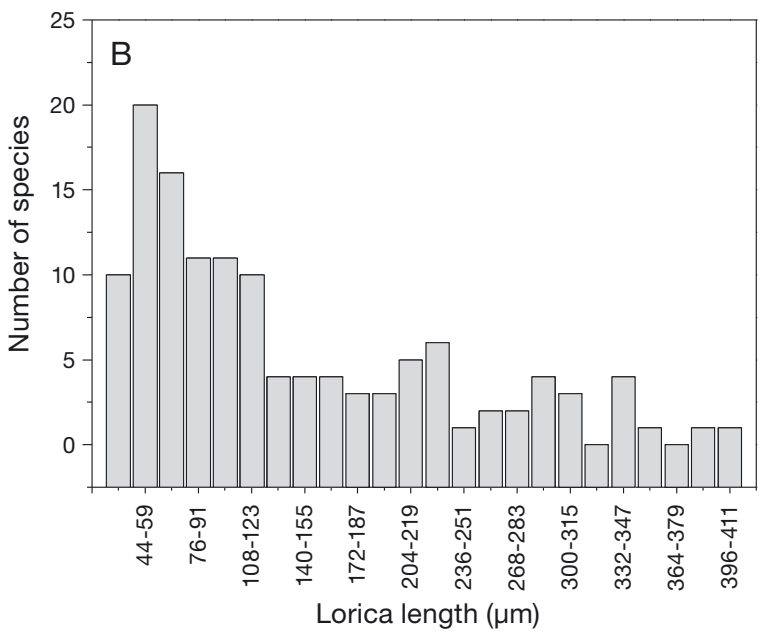

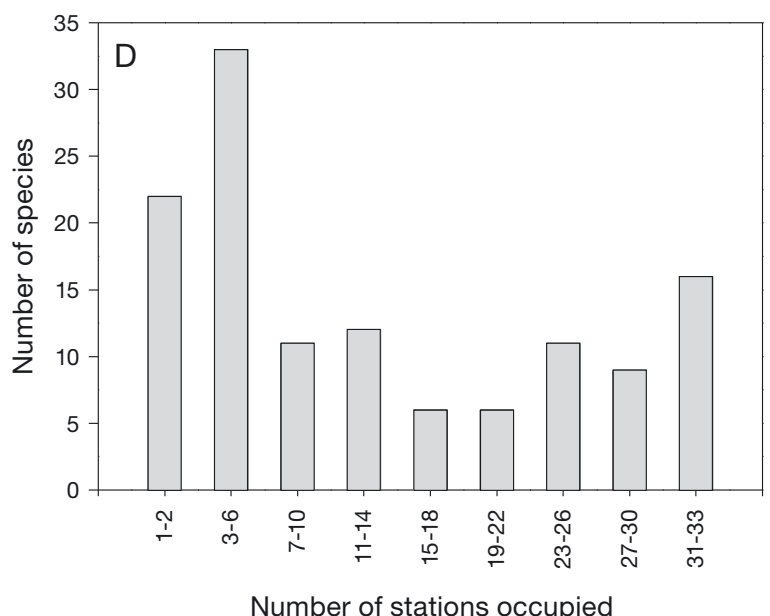

Fig. 3. Distributions of species in size-classes of (A) lorica oral diameter, (B) lorica length, (C) log lorica volume and (D) number of stations occupied
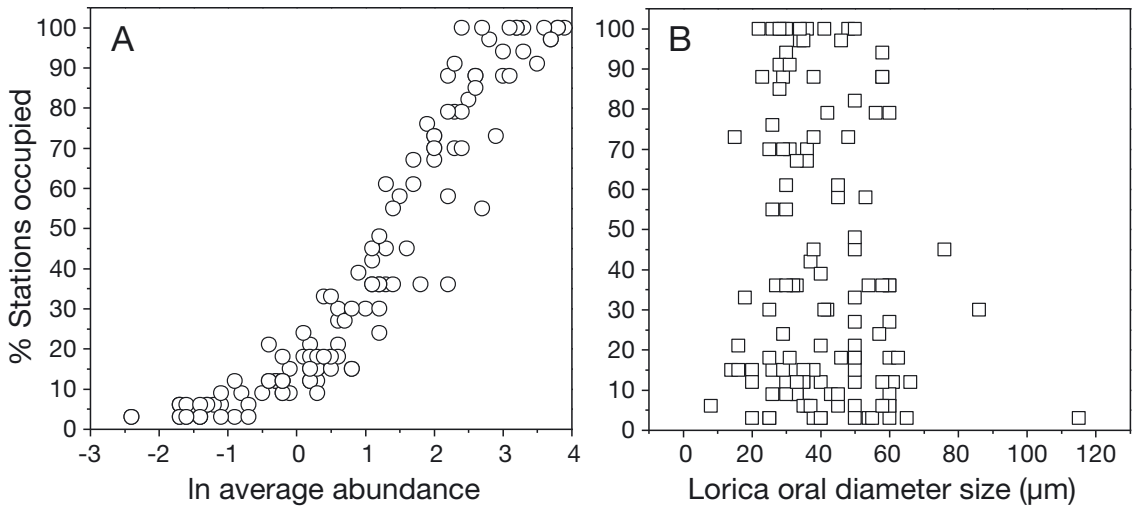

Fig. 4. (A) Abundance and occurrence rates and (B) lorica oral diameter size and occurrence rates of tintinnid species as a percentage of stations occupied among all the stations

Kolmogorov-Smirnov and Shapiro-Wilks tests ( $p>$ 0.05 ); species richness was significantly positively and linearly correlated with $\log _{10}$ (abundance) (Pearson correlation $r=0.43, p=0.01$ ), with the function of the relationship as species richness $=8.45 \log _{10}$ (abundance) $+26.9, R^{2}=0.16, p<0.05$ (Fig. 5D). There were no sig- nificant correlations between the diversity metrics and either integrated chl a concentration or chl $a-H^{\prime}$, but all diversity parameters were negatively significantly correlated with DCM depth (Table 2). Additionally, morphological diversity metrics were significantly positively correlated with species richness $(p<0.05)$. 

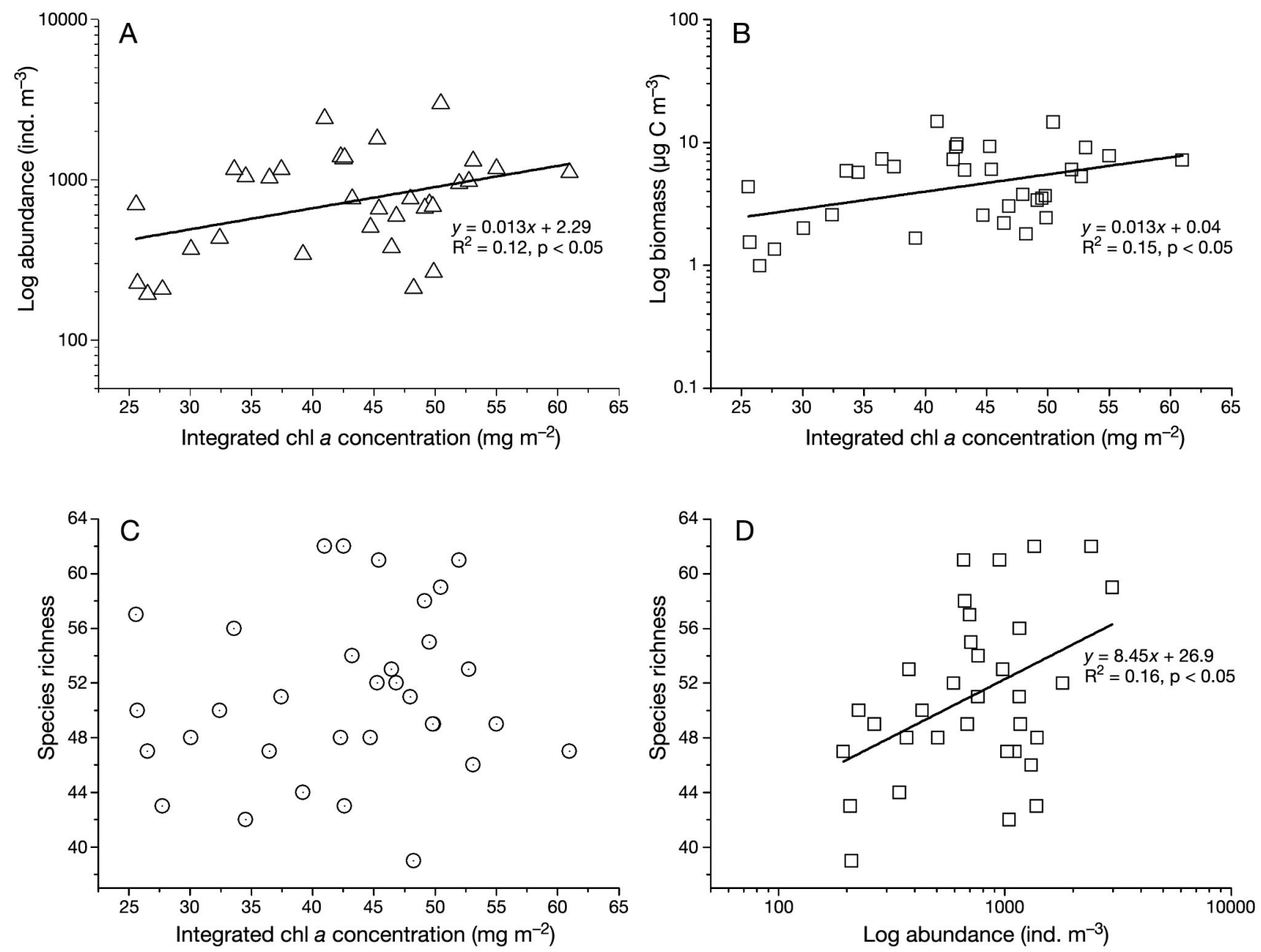

Fig. 5. Relationship between tintinnid (A) abundance, (B) biomass, (C) species richness and integrated chl a concentration, and (D) between species richness and tintinnid abundance

Table 2. Spearman's rank correlation coefficients among metrics of diversity of tintinnids, their abundance and characteristics of chl a. Characteristics of chl a concentration included integrated chl a concentration, Shannon-Wiener index of chl a size-class concentration in the water column of 0-200 $\mathrm{m}\left(\mathrm{chl} a-H^{\prime}\right)$ and the depth of the deep chlorophyll maximum (DCM) layer. Taxonomic metrics were species richness (numbers of species), the Shannon-Wiener index $\left(H^{\prime}\right)$ and Fisher's alpha. Morphological metrics were numbers of lorica oral diameters (in $4 \mu \mathrm{m}$ size-classes, LOD s-c) and the Shannon-Wiener index of LOD (LOD- $\left.H^{\prime}\right)$. For all pairs, $\mathrm{n}=33$, except chl $a-H^{\prime}$ where $\mathrm{n}=26 .{ }^{*} \mathrm{p}<0.01,{ }^{* *} \mathrm{p}<0.05$

\begin{tabular}{|lccccc|}
\hline & $\begin{array}{c}\text { Species } \\
\text { richness }\end{array}$ & $H^{\prime}$ & $\begin{array}{c}\text { Fisher's } \\
\text { alpha }\end{array}$ & LOD s-c & LOD- $H^{\prime}$ \\
\hline Log $_{10}$ (abundance) & 0.29 & 0.089 & $-0.81^{* *}$ & 0.20 & -0.09 \\
Integrated chl $a$ & 0.14 & -0.04 & -0.27 & 0.26 & 0.09 \\
Chl $a-H^{\prime}(\mathrm{n}=26)$ & -0.09 & 0.03 & 0.20 & -0.23 & -0.06 \\
Depth of DCM & $-0.46^{* *}$ & $-0.43^{*}$ & $-0.46^{* *}$ & $-0.43^{*}$ & $-0.50^{* *}$ \\
Species richness & & $0.73^{* *}$ & 0.24 & $0.52^{* *}$ & $0.42^{*}$ \\
$H^{\prime}$ & $0.73^{* *}$ & & 0.33 & 0.31 & $0.54^{* *}$ \\
Fisher's alpha & 0.24 & 0.33 & & 0.14 & $0.41^{*}$ \\
LOD s-c & $0.52^{* *}$ & 0.31 & 0.14 & & 0.34 \\
LOD- $H^{\prime}$ & $0.42^{*}$ & $0.54^{* *}$ & $0.41^{*}$ & 0.34 & \\
\hline
\end{tabular}

We presented our data as a rank-abundance distribution with different models associated with different assumptions. SAD was fitted to the geometric, log-normal, log-series and mZSM distributions for 33 stations by the AIC statistic. The mZSM distribution provided the best fit at Stn I206, with the best fit given by geometric distribution at Stn I705 (see Fig. S1 in the Supplement at www.int-res.com/articles/ suppl/b026p087_supp.pdf). The log-normal distribution gave the best fit compared with the other models at the other 31 stations. The tintinnid distributions in the 3 zones best fitted the log-normal distribution (Fig. 6, Table 3). Replacing the species rank with LOD size-class, the geometric distribution gave the best fit in the NEQ and SEQ zones. However, the LOD size-class distributions in the EQ zone best fitted the log-normal distribution (Table 3, Fig.7). 

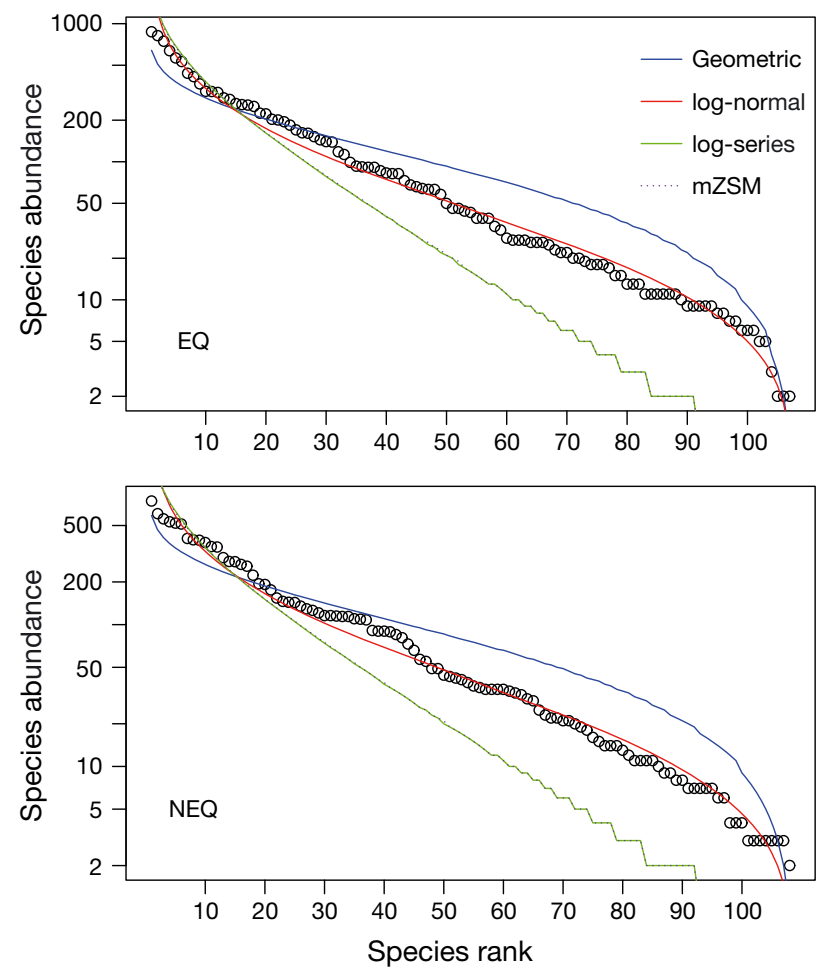

\section{DISCUSSION}

\section{Relationship between community diversity and chl a concentration}

Our research area in the eastern equatorial Indian Ocean covered $\sim 1500 \mathrm{~km}$ in longitude and $>1200 \mathrm{~km}$ in latitude. Species distribution conformed to the general pattern of abundant species being more widespread than rare or less abundant species, similar to that in the southeast tropical Pacific Ocean (Dolan et al. 2007) and the sub-polar Strait of Magellan (Fonda Umani et al. 2011). Seven of the 20 tintinnid species found in the Bay of Bengal (Liu et al. 2012) and 23 of the 45 species found in the neighboring Indian Ocean (Modigh et al. 2003) were recorded in the present study. Compared with other oceanic waters, except for the tropical Pacific Ocean and Southern Ocean, higher tintinnid species richness and lower abundance and biomass were found in the eastern equatorial Indian Ocean (Table 4), although methodological and geographical differences may have led to the difference in results. Low chl a concentration did not reduce tintinnid species richness but may serve as the cause of low abundance and biomass. Tintinnid abundance and biomass showed significant and positive linear correlation with integrated chl a concentration (Fig. 5A,B), supporting this suggestion.

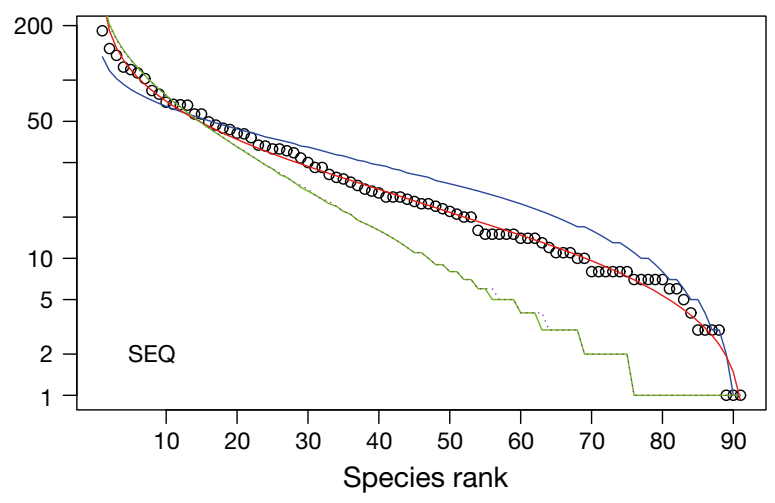

Fig. 6. The species abundance distribution best fitted by the log-normal distribution in the EQ, NEQ and SEQ regions. Actual observed abundances are shown (circles); lines are the expected abundances from 4 theoretical distributions. Dotted lines for mZSM distribution are used to differentiate from the log-series distribution. EQ: equator; NEQ: northern zone of the equator; SEQ: southern zone of the equator; mZSM: meta-community zero-sum multinominal

Positive correlation and co-variation between food concentration $(\mathrm{chl} a)$ and tintinnid stocks are reported in many studies (Godhantaraman 2002, Dolan et al. $2006 a, b, 2007)$. Variability in abundance $(12 \%)$ and biomass (15\%) explained by integrated chl a from the positive linear relationships, as well as $16 \%$ variability in species richness explained by abundance from the linear regression model, were slightly lower than results in the oceanic water of the southwest Atlantic

Table 3. Results of the analysis of tintinnid species abundance distribution (SAD) and LOD size-class abundance distribution. LOD: lorica oral diameter; AIC: Akaike's information criterion; EQ: equator; NEQ: northern zone of the equator; SEQ: southern zone of the equator; mZSM: meta-community zero-sum multinominal. Bold: lowest AIC value, indicating the closest fits

\begin{tabular}{|lcccccc|}
\hline \multirow{2}{*}{ Zone } & \multirow{2}{*}{$\begin{array}{c}\text { No. of } \\
\text { stns }\end{array}$} & $\begin{array}{c}\text { Species } \\
\text { richness }\end{array}$ & $\begin{array}{c}\text { Geo- } \\
\text { metric }\end{array}$ & $\begin{array}{c}\text { Log- } \\
\text { normal }\end{array}$ & $\begin{array}{c}\text { Log- } \\
\text { series }\end{array}$ & mZSM \\
\hline SAD fits & & \multicolumn{7}{c}{ malue } \\
EQ & 15 & 106 & 1228.84 & $\mathbf{1 1 9 7 . 0 0}$ & 1246.98 & 1246.44 \\
NEQ & 12 & 105 & 1202.28 & $\mathbf{1 1 7 6 . 8 4}$ & 1223.50 & 1222.92 \\
SEQ & 6 & 91 & 918.37 & $\mathbf{9 0 2 . 3 1}$ & 941.43 & 940.93 \\
LOD abundance distribution fits & & & \\
EQ & 15 & 14 & 220.34 & $\mathbf{2 1 8 . 2 8}$ & 222.64 & 222.74 \\
NEQ & 12 & 14 & $\mathbf{2 1 8 . 0 8}$ & 220.26 & 229.80 & 228.90 \\
SEQ & 6 & 11 & $\mathbf{1 5 9 . 0 8}$ & 159.56 & 176.32 & 175.40 \\
\hline
\end{tabular}



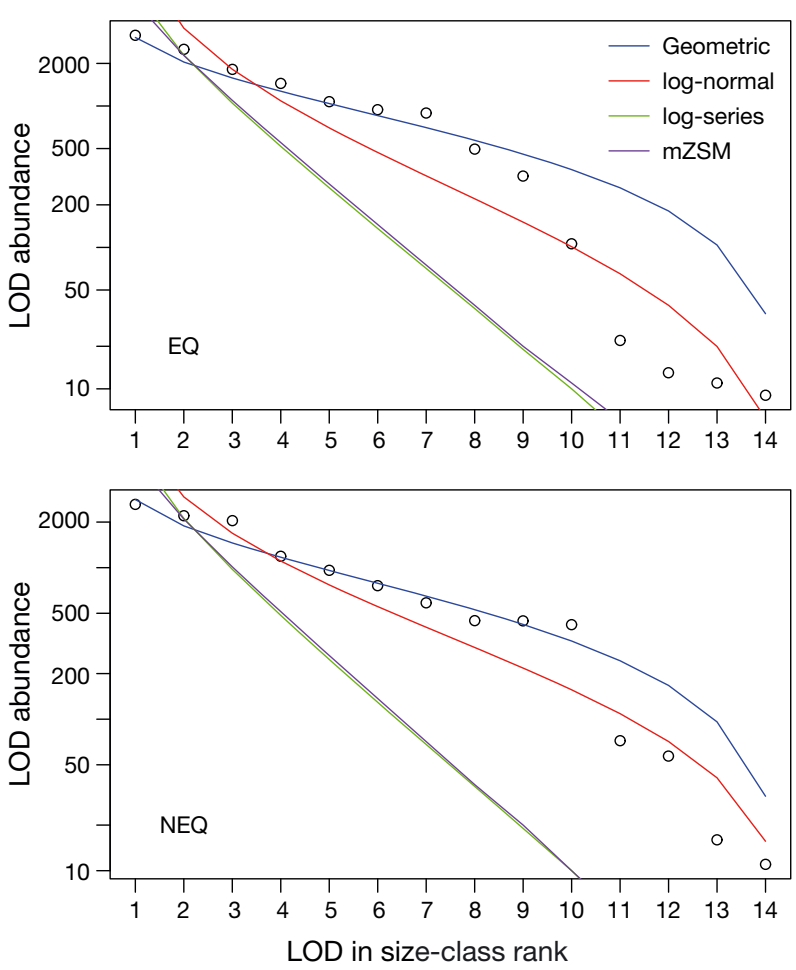

(Santoferrara \& Alder 2012). Many studies reveal that resources appear to have a direct influence on diversity. No significant correlation between species richness and chl a concentration was found in this study, corresponding to Dolan et al. (2007), and differing from the positive correlation (Dolan et al. 2006a, Santoferrara \& Alder 2012) and negative correlation (Dolan 2000, Thompson 2004) found in other studies.

Most ecological models predict that the diversityproductivity relationship should have a unimodal pattern, with maximal diversity at intermediate levels of productivity (Waide et al. 1999, Mittelbach

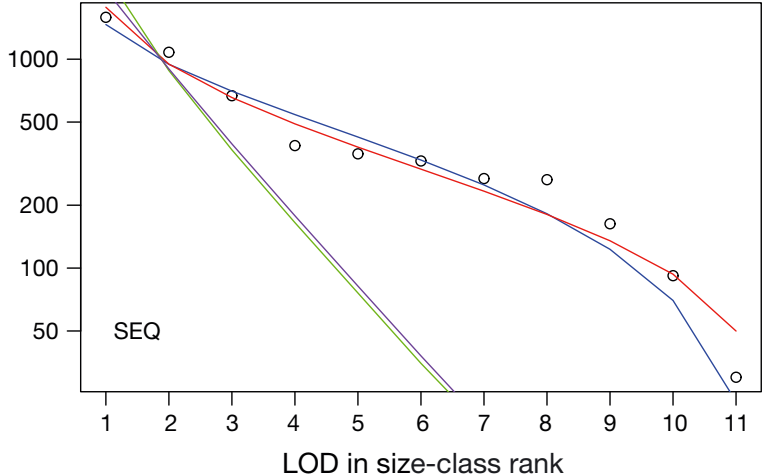

Fig. 7. LOD in size-class abundance distribution in the EQ, NEQ and SEQ zones. Log-normal distribution gave the best fit on the EQ; the geometric distribution showed best fit in the NEQ and SEQ zones. Actual observed abundances are shown (circles); lines are the expected abundances from 4 theoretical distributions. See Table 3 for abbreviations

et al. 2001). Furthermore, considering the regional spatial scale (Chase \& Leibold 2002) and low productivity in the equatorial Indian Ocean, species richness should increase with productivity. The above discrepancy may have 2 explanations: (1) the sampling methods or data processing were different. Chl a concentrations at different water depths varied as much within stations as between stations. As tintinnids were sampled over the integrated $0-200 \mathrm{~m}$ water column, chl a concentration from several water layers in one station were integrated by the trapezoidal method to correspond to the tintinnid commu-

Table 4. Comparison of species composition of tintinnid communities. Pooling data: data pooled for all samples (20 $\mu \mathrm{m}$ mesh) from all discrete depths of 1 station; bottle: bottle sampling

\begin{tabular}{|c|c|c|c|c|c|c|}
\hline Study area & $\begin{array}{l}\text { Sampling } \\
\text { method }\end{array}$ & $\begin{array}{l}\text { No. of } \\
\text { species }\end{array}$ & $\begin{array}{l}\text { Abundance } \\
\text { (ind. } \mathrm{dm}^{-3} \text { ) }\end{array}$ & $\begin{array}{c}\text { Biomass } \\
\left(\mu \mathrm{g} \mathrm{C} \mathrm{dm}{ }^{-3}\right)\end{array}$ & $\begin{array}{c}\text { Chl a } \\
\left(\mathrm{mg} \mathrm{m}^{-3}\right)\end{array}$ & Reference \\
\hline Indian Ocean $\left(42^{\circ} \mathrm{N}-43^{\circ} \mathrm{S}\right)$ & Surface $(20 \mu \mathrm{m})$ & 86 & 10 & - & $<0.5$ & Modigh et al. (2003) \\
\hline SE tropical Pacific Ocean & Pooling data & 149 & $2-40$ & - & $0.07-2$ & Dolan et al. (2007) \\
\hline $\begin{array}{l}\text { Kongsfjorden, Svalbard } \\
\text { (Arctic) }\end{array}$ & Bottle & 8 & $<1-2435$ & $0-6.33$ & $0.07-0.43$ & Feng et al. (2014) \\
\hline Southern Ocean & Net & 192 & - & - & - & Dolan et al. (2012) \\
\hline SW Atlantic & Bottle $(10 \mu \mathrm{m})$ & 60 & 76 & 0.14 & $1-2.4$ & $\begin{array}{l}\text { Thompson \& Alder } \\
\text { (2005) }\end{array}$ \\
\hline Mediterranean & Pooling data & 90 & 25 & - & $0.1-0.45$ & Dolan (2000) \\
\hline Bay of Bengal & Bottle & 20 & $<40$ & - & - & Liu et al. (2012) \\
\hline Eastern India Ocean & Net $(20 \mu \mathrm{m})$ & 126 & $<1-3$ & $<0.001-0.014$ & 0.17 & This study \\
\hline
\end{tabular}


nity (2) The quality of the available resources may have affected the trophic differences of tintinnids in the different areas. Besides phytoplankton, they may feed on the heterotrophic nanoflagellate and organic matter content with suitable size (Sitran et al. 2009).

\section{Water column stratification and tintinnid diversity}

Underlying water column features are reported to be very relevant to tintinnid species diversity and distribution patterns (Thompson et al. 1999, Sitran et al. 2009). Possible shifts in species within a tintinnid community have also been attributed to changes in environmental conditions (Gavrilova \& Dolan 2007).

Eastward wind stresses during the spring intermonsoon lead to convergence on the equator (Schott et al. 2002). Shallow mixed layers resulting from stirring by weak winds and increased solar heating are a characteristic feature of the spring inter-monsoon (Wiggert et al. 2006, Longhurst 2007). As a result of the freshwater input from rivers and from precipitation, the surface salinity clearly decreased. Surface chl a concentrations were relatively higher in the NEQ than in other zones, particularly in the $6^{\circ} \mathrm{N}$ transect and at Stns I301-I303 and I711-I712 near Sri Lanka (Fig. 2). The mixed layer was found to be thinner in the NEQ and SEQ than in the EQ zone. Strong stratification of surface waters because of freshwater effects curtails nutrient entrainment from deeper waters, leading to weak productivity associated with subsurface DCM when surface nutrients are depleted (Unger \& Jennerjahn 2009). The average integrated chl a concentration in the NEQ and SEQ zones was less than that in the EQ zone, and the percentage of nano-chl $a$ in the total chl a concentration in the NEQ and SEQ zones was, on average, higher than in the EQ zone ( 25 versus $16 \%$ ).

Some previous research reveals that tintinnid diversity is positively related to the depth of the DCM layer (Dolan 2000, Dolan et al. 2007), whereas other research finds no particular relationship between these variables (Dolan et al. 2002). We found that taxonomic and morphological diversity were negatively correlated to the depth of the DCM layer (Table 2). Annual sea surface temperature, as a proxy measure of depth of the surface layer, probably reflects the number of niches available with depth (Rutherford et al. 1999). Planktonic diversity does not show a simple relationship with water column structure (Dolan et al. 2006b); thus, it is still uncertain how depth of the DCM representing water column structure can influence diversity.

\section{Taxonomic and morphological diversity}

The maximal prey size ingested by tintinnids is $\sim 45 \%$ of the LOD and preferred prey size is $\sim 25 \%$ of the LOD (Heinbokel 1978, Dolan et al. 2002). More than $70 \%$ of total species (98 of 126) occurred in 6 of the 15 LOD size-classes, and this plays an important role in structuring the community. The top 10 numerically dominant species, including Acanthostomella minutissima, Steenstrupiella gracilis, Amphorides quadrilineata, Protorhabdonella simplex, S. intumescens, S. steenstrupii, Salpingella minutissima, Dadayiella ganymedes, D. acutiformis, Eutintinnus lusus-undae exhibited similar LOD sizes ranging from 22 to $48 \mu \mathrm{m}$. These species prey most efficiently on nano-food within the narrow range of 5.5-12 $\mu \mathrm{m}$ diameter. A close relationship between taxonomic diversity and morphological diversity was confirmed in our study. Across the stations, the number of tintinnid species was positively related to numbers of distinct LOD size-classes $(\mathrm{n}=33, \rho=0.52, \mathrm{p}=0.002)$ and the Shannon-Wiener index of LOD $(\mathrm{n}=33, \rho=0.42, \mathrm{p}=$ 0.015) (Table 2, Fig. 8A). In terms of high species richness at different stations, per-LOD size-class was occupied by an average of 4 to 6 species.

As a conservative and relatively reliable species characteristic, LOD not only explains the large morphological variety displayed by the group but also reflects adaptation to distinct ecological niches (Dolan 2010). Geometric distribution based on an assumption of niche partitioning has been used to describe distribution of LOD size-class abundance in the Mediterranean gyre (Dolan et al. 2013) and the SAD of total planktonic ciliates in the Gulf of Aqaba (Claessens et al. 2010) and in Antarctic waters (Wickham et al. 2011). Geometric distribution is always relevant to species-poor and/or harsh environments where relatively few factors determine the niche (Magurran 1988). A geometric distribution of LOD size-classes in the NEQ and SEQ zones and the lognormal distribution in the EQ zone (Fig. 7, Table 3) were related to resource partitioning and the availability of prey concentration and size. This suggests heterogeneous environmental conditions in the 3 zones.

Compared with the EQ zone, the NEQ and SEQ zones displayed a shallower mixed layer and lower average integrated chl a concentration. As the SEQ zone comprised only 6 stations, we combined the SEQ and NEQ zones when considering the relationship between the number of species and the number of LOD size-classes. In the EQ zone, the number of species was not correlated with the number of LOD 

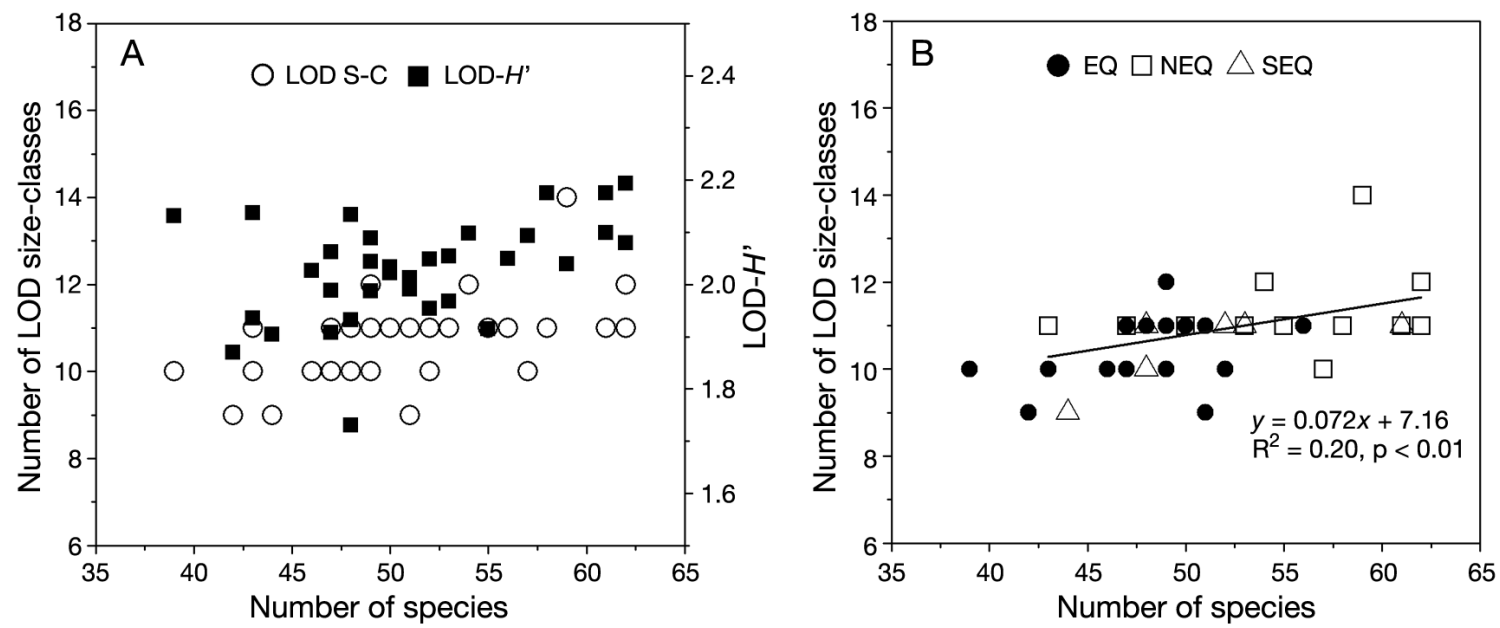

Fig. 8. Relationships between (A) the number of species versus numbers of LOD size-classes and LOD- $H$, and (B) between the number of species and the number of LOD size-classes in the EQ, NEQ and SEQ regions. Regression line is shown for the NEQ and SEQ. See Table 3 for abbreviations

size-classes, but there was positive correlation $(\mathrm{n}=$ 18 , Spearman's $\rho=0.73, \mathrm{p}<0.01$ ) between them in the SEQ and NEQ zones. The relationship was represented by the linear regression $\left(\mathrm{R}^{2}=0.2, \mathrm{p}<0.01\right.$; Fig. 8B).

\section{Mechanism governing community diversity}

Most studies show that SAD for tintinnid ciliates generally matches a log-series distribution across the southeastern Pacific Ocean (Dolan et al. 2007), in the northwestern Mediterranean Sea (Dolan et al. 2009, Raybaud et al. 2009) and in the California Current (Dolan et al. 2013), coherent with the neutral theory of community. Log-series, like SADs of marine organisms such as diatoms, follows from neutral models of biodiversity and reveals near ecological equivalence among species (Pueyo 2006). The unified neutral theory suggests that relative abundance of taxa in the community is determined by stochastic random immigration, births and deaths (Hubbell 2001, McGill et al. 2007). In contrast, tintinnid communities in the coastal Mediterranean Sea (Sitran et al. 2009) and in this study revealed log-normal SADs.

A log-normal SAD predicts a more even distribution of resources, typically when the niche is multidimensional or the abundance of each species in a community is determined by largely independent factors acting multiplicatively on each species (Magurran 1988). The number of species at different stations was in the range of 39-62, in accord with an assumption of a large community with $>30$ species in the model of lognormal distribution.
The size structure of phytoplankton dominated by pico- $(74.1 \%)$ and nano-phytoplankton $(22.2 \%)$ may play a leading role in the range of LOD. The LOD of more than $70 \%$ of the species, limited to 6 sizeclasses, seemed to imply an immense amount of niche overlap. Geometric distribution of LOD sizeclasses in the NEQ and SEQ zones, however, revealed the dominant role of partially available resources or niche spaces for species with different LOD size-classes, with a tight correlation between the number of species and the number of LOD sizeclasses. Distribution of LOD size-classes in the EQ zone exhibited the typical lognormal distribution for most natural assemblages. While phytoplankton biomass was lower during the inter-monsoon compared with monsoon seasons, bacterial production was highest in the Indian Ocean (Ramaiah et al. 2009). High bacterial extracellular enzymatic activities (Caruso et al. 2004) enabled a trophic difference in available resources (e.g. heterotrophic nanoplankton and particulate organic matter) among tintinnids in microbial food webs of oceanic waters. Interacting tintinnid species are, apparently, not ecologically equivalent, a central assumption of neutral theory.

According to the procedure described in Magurran \& Henderson (2003), 98 core tintinnid species accounted for $99 \%$ of total abundance; the rest comprised 28 rare species, contributing only $1 \%$ of total abundance. There are distinct predictions about the proportions of very rare species between log-normal and log-series distribution, high in log-series, low in log-normal (McGill et al. 2007). It was shown that the percentage of rare species in the tintinnid assemblage of the eastern Indian Ocean was lower than in 
the open water of the Mediterranean Sea (22.2 vs. $81.7 \%$ ) (Dolan et al. 2009)

Analysis of water stratification showed different hydrographic conditions among the EQ, NEQ and SEQ zones. In the EQ zone, the thermocline and halocline tended to be horizontally steadier and the DCM layer deeper, relative to the 2 other zones. Changes in mixed-layer depths in the NEQ and SEQ related to nutrient state and decreased phytoplankton biomass. Tintinnid assemblages were influenced by the resource partitioning through the close relationship between LOD size and prey exploited. Moreover, taxonomic and morphological diversity of all stations decreased with the depth of the DCM layer. Under the heterogeneous environmental conditions, the community is driven by non-neutral processes such as competition and niche partitioning (Sitran et al. 2009). The tintinnid community in the eastern Indian Ocean can, therefore, be described as having a log-normal pattern driven by water-column environmental factors such as competition and niche partitioning, rather than by neutral dispersal of species.

Acknowledgements. This study was supported by the National Key Scientific Research Program (2015CB954002), the National Natural Science Foundation of China (nos. 41276124, 413061194 and 41676112), the National Open Research Cruise project (NORC) for the Eastern Indian Ocean, the University Innovation Team Training Program for Tianjin (TD12-5003) and the Program for Changjiang Scholars to J.S. We thank the scientists, officers and crew of RV 'Shiyan 1' for their assistance with sampling. We are also grateful to Dr. Yunkai He for the CTD measurements. We also thank Paulo Inácio Prado for statistical assistance and Haijiao Liu for suggestions to improve the language in this manuscript.

\section{LITERATURE CITED}

Agatha S, Laval-Peuto M, Simon P (2013) The tintinnid lorica. In: Dolan JR, Montagnes DJS, Agatha S, Coats DW, Stoecker DK (eds) The biology and ecology of tintinnid ciliates: models for marine plankton. Wiley-Blackwell, Chichester, p 17-41

* Bachy C, Gómez F, López-García P, Dolan JR, Moreira D (2012) Molecular phylogeny of tintinnid ciliates (Tintinnida, Ciliophora). Protist 163:873-887

Burnham KP, Anderson DR (2002) Model selection and multi-model inference: a practical information-theoretic approach. Springer, New York, NY

Calbet A, Landry MR (1999) Mesozooplankton influences on the microbial food web: direct and indirect trophic interactions in the oligotrophic open ocean. Limnol Oceanogr 44:1370-1380

Caruso G, Decembrini F, Azzaro F, Raffa F, Galletta M (2004) Bacterial extracellular enzymatic activities in a Tyrrhenian ecosystem (Milazzo Gulf). Rapp Comm Int Mer Medit 37:268
Chase JM, Leibold MA (2002) Spatial scale dictates the productivity-biodiversity relationship. Nature 416:427-430

Claessens M, Wickham SA, Post AF, Reuter M (2010) A paradox of the ciliates? High ciliate diversity in a resourcepoor environment. Mar Biol 157:483-494

Dolan JR (2000) Tintinnid ciliate diversity in the Mediterranean Sea: longitudinal patterns related to water column structure in late spring-early summer. Aquat Microb Ecol 22:69-78

Dolan JR (2010) Morphology and ecology in tintinnid ciliates of the marine plankton: correlates of lorica dimensions. Acta Protozool 49:235-244

Dolan JR, Pierce RW (2013) Diversity and distributions of tintinnids. In: Dolan JR, Montagnes DJS, Agatha S, Coats DW, Stoecker DK (eds) The biological and ecology of tintinnid ciliates: models for marine plankton. WileyBlackwell, Chichester, p 216-243

* Dolan JR, Vidussi F, Claustre H (1999) Planktonic ciliates in the Mediterranean Sea: longitudinal trends. Deep-Sea Res I 46:2025-2039

*Dolan JR, Claustre H, Carlotti F, Plounevez S, Moutin T (2002) Microzooplankton diversity: relationships of tintinnid ciliates with resources, competitors and predators from the Atlantic coast of Morocco to the eastern Mediterranean. Deep-Sea Res I 49:1217-1232

Dolan JR, Jacquet S, Torreton JP (2006a) Comparing taxonomic and morphological biodiversity of tintinnids (planktonic ciliates) of New Caledonia. Limnol Oceanogr 51: 950-958

* Dolan JR, Lemee R, Gasparini S, Mousseau L, Heyndrickx C (2006b) Probing diversity in the plankton: using patterns in tintinnids (planktonic marine ciliates) to identify mechanisms. Hydrobiologia 555:143-157

* Dolan JR, Ritchie ME, Ras J (2007) The 'neutral' community structure of planktonic herbivores, tintinnid ciliates of the microzooplankton, across the SE tropical Pacific Ocean. Biogeosciences 4:297-310

*Dolan JR, Ritchie ME, Tunin-Ley A, Pizay MD (2009) Dynamics of core and occasional species in the marine plankton: tintinnid ciliates in the north-west Mediterranean Sea. J Biogeogr 36:887-895

* Dolan JR, Pierce RW, Yang EJ, Kim SY (2012) Southern Ocean biogeography of tintinnid ciliates of the marine plankton. J Eukaryot Microbiol 59:511-519

* Dolan JR, Landry MR, Ritchie ME (2013) The species-rich assemblages of tintinnids (marine planktonic protists) are structured by mouth size. ISME J 7:1237-1243

* Feng M, Zhang W, Xiao T (2014) Spatial and temporal distribution of tintinnid (Ciliophora: Tintinnida) communities in Kongsfjorden, Svalbard (Arctic), during summer. Polar Biol 37:291-296

Fonda Umani S, Monti M, Cataletto B, Budillon G (2011) Tintinnid distributions in the Strait of Magellan (Chile). Polar Biol 34:1285-1299

Gavrilova N, Dolan J (2007) A note on species lists and ecosystem shifts: Black Sea tintinnids, ciliates of the microzooplankton. Acta Protozool 46:279-288

*Godhantaraman N (2002) Seasonal variations in species composition, abundance, biomass and estimated production rates of tintinnids at tropical estuarine and mangrove waters, Parangipettai, southeast coast of India. J Mar Syst 36:161-171

Hada Y (1938) Studies on the Tintinnoinea from the western tropical Pacific. J Fac Sci Hokkaido Univ Zool 6:87-190

Keinbokel J (1978) Studies on the functional role of tintin- 
nids in the Southern California Bight. II. Grazing rates of field populations. Mar Biol 47:191-197

Hubbell SP (2001) The unified neutral theory of biodiversity and biogeography. Princeton University Press, Princeton, NJ

Kofoid C, Campbell A (1929) A conspectus of the marine and fresh-water ciliate belonging to the suborder Tintinnoinea, with descriptions of new species principally from the Agassiz expedition to the eastern tropical Pacific 1904-1905. Univ Calif Publ Zool 34:1-104

Kofoid CA, Campbell AS (1939) The Tintinnoinea of the eastern tropical Pacific. Bull Mus Comp Zool 84:1-473

Liu H, Li G, Huang L, Huang J, Ke Z, Tan Y (2012) Community structure and abundance of tintinnids in the Bay of Bengal during the spring. Am J Agric Biol Sci 7:407-411

Longhurst AR (2007) Ecological geography of the sea. Academic Press, San Diego, CA

Magurran AE (1988) Ecological diversity and its measurement. Croom Helm, London

Magurran AE (2004) Measuring biological diversity. Blackwell Science, Chichester

Magurran AE, Henderson PA (2003) Explaining the excess of rare species in natural species abundance distributions. Nature 422:714-716

Marshall SM (1969) Protozoa: Order Tintinnida. In: Fraser JH, Hansen VK (eds) Fiches d'identification de zooplancton. Conseil International pour l'Exploration de la Mer, Les Presses Saint-Augustin, Bruges, p 117-127

McGill BJ, Etienne RS, Gray JS, Alonso D and others (2007) Species abundance distributions: moving beyond single prediction theories to integration within an ecological framework. Ecol Lett 10:995-1015

Mittelbach GG, Steiner CF, Scheiner SM, Gross KL and others (2001) What is the observed relationship between species richness and productivity? Ecology 82: 2381-2396

Modigh M, Castaldo S, Saggiomo M, Santarpia I (2003) Distribution of tintinnid species from $42^{\circ} \mathrm{N}$ to $43^{\circ} \mathrm{S}$ through the Indian Ocean. Hydrobiologia 503:251-262

Murtugudde R, McCreary JP, Busalacchi AJ (2000) Oceanic processes associated with anomalous events in the Indian Ocean with relevance to 1997-1998. J Geophys Res 105: 3295-3306

Parsons T, Maita Y, Lalli C (1984) A manual of chemical and biological methods for seawater analysis. Pergamon Press, Oxford

Pierce RW, Turner JT (1992) Ecology of planktonic ciliates in marine food webs. Rev Aquat Sci 6:139-181

Pierce RW, Turner JT (1993) Global biogeography of marine tintinnids. Mar Ecol Prog Ser 94:11-26

Prado PI, Miranda MD (2015) Fitting species abundance models with maximum likelihood: quick reference for sads package. http://ftp.heanet.ie/mirrors/cran.r-project. org/web/packages/sads/vignettes/sads_intro.pdf

Pueyo S (2006) Diversity: between neutrality and structure. Oikos 112:392-405

Ramaiah N, Fernandes V, Rodrigues VV, Paul JT, Gauns M (2009) Bacterioplankton abundance and production in Indian Ocean regions. In: Wiggert J, Hood RR, Naqvi SWA, Brink KH, Smith SL (eds) Indian Ocean biogeochemical processes and ecological variability. American
Geophysical Union, Washington, DC, p 119-132

* Raybaud V, Tunin-Ley A, Ritchie M, Dolan J (2009) Similar patterns of patterns of community organization characterize distinct groups of different trophic levels in the plankton of the NW Mediterranean Sea. Biogeosciences 6:431-438

* Rutherford S, D'Hondt S, Prell W (1999) Environmental controls on the geographic distribution of zooplankton diversity. Nature 400:749-753

Santoferrara LF, Alder VA (2012) Abundance and diversity of tintinnids (planktonic ciliates) under contrasting levels of productivity in the Argentine Shelf and Drake Passage. J Sea Res 71:25-30

Schott FA, Dengler M, Schoenefeldt R (2002) The shallow overturning circulation of the Indian Ocean. Prog Oceanogr 53:57-103

* Shankar D, Vinayachandran P, Unnikrishnan A (2002) The monsoon currents in the north Indian Ocean. Prog Oceanogr 52:63-120

Sitran R, Bergamasco A, Decembrini F, Guglielmo L (2009) Microzooplankton (tintinnid ciliates) diversity: coastal community structure and driving mechanisms in the southern Tyrrhenian Sea (western Mediterranean). J Plankton Res 31:153-170

Strutton PG, Coles VJ, Hood RR, Matear RJ, McPhaden MJ, Phillips HE (2015) Biogeochemical variability in the central equatorial Indian Ocean during the monsoon transition. Biogeosciences 12:2367-2382

Thompson GA (2004) Tintinnid diversity trends in the southwestern Atlantic Ocean (29 to $\left.60^{\circ} \mathrm{S}\right)$. Aquat Microb Ecol 35:93-103

* Thompson GA, Alder VA (2005) Patterns in tintinnid species composition and abundance in relation to hydrological conditions of the southwestern Atlantic during austral spring. Aquat Microb Ecol 40:85-101

Thompson GA, Alder VA, Boltovskoy D, Brandini F (1999) Abundence and biogeography of tintinnids (Ciliophora) and associated microzooplankton in the southwestern Atlantic Ocean. J Plankton Res 21:1265-1298

Unger D, Jennerjahn T (2009) Impact of regional Indian Ocean characteristics on the biogeochemical variability of settling particles. In: Wiggert J, Hood RR, Naqvi SWA, Brink KH, Smith SL (eds) Indian Ocean biogeochemical processes and ecological variability. American Geophysical Union, Washington, DC, p 257-280

*Verity PG, Langdon C (1984) Relationships between lorica volume, carbon, nitrogen, and ATP content of tintinnids in Narragansett Bay. J Plankton Res 6:859-868

Waide R, Willig M, Steiner C, Mittelbach G and others (1999) The relationship between productivity and species richness. Annu Rev Ecol Syst 30:257-300

Whittaker RH (1972) Evolution and measurement of species diversity. Taxon 21:213-251

Wickham SA, Steinmair U, Kamennaya N (2011) Ciliate distributions and forcing factors in the Amundsen and Bellingshausen Seas (Antarctic). Aquat Microb Ecol 62: 215-230

Wiggert J, Murtugudde R, Christian J (2006) Annual ecosystem variability in the tropical Indian Ocean: results of a coupled bio-physical ocean general circulation model. Deep-Sea Res II 53:644-676

Submitted: September 8, 2016; Accepted: April 24, 2017

Proofs received from author(s): June 11, 2017
Editorial responsibility: J. Rudi Strickler, Milwaukee, Wisconsin, USA 